\title{
Western Influences on the three Bengali Poets of the 30s
}

\author{
Sultana Jahan
}

Assistant Professor, Department of English Language and Literature, International Islamic University Chittagong, Bangladesh

\begin{abstract}
Modernism came to exercise an influence in Bangladesh's poets in the way it once did with Baudelaire and Eliot. For these western poets, the romantic notion was replaced with desperation and despondency and loneliness of modern minds. JibanadaDas, Budda Dev Bose, shudindranath Dutt, Amiochacrabarti, and Bishnudey, all of them being the professors of English Literature, successfully incorporated Western Modernist outlook with a view to shaking off Tagore's romantic perception.They were much influenced by French imagist and symbolist movement, French surrealist poets, Garman expressionist poets and other modernists. Sometimes they incorporates Eatsian ideology, sometimes they followed Eliotic view, and sometimes they followed Marxist Theory or Freudian psychoanalysis. Though, these modernist poets take on different styles and ways to reveal the alienation, hypocrisy and anxiety of modern man, they perceive the fact that to reflect the post-war modern world, there is no alternative of discarding romantic notion about life. This paper will shed light on three poets, Jibananda Das, AmioCakrabarti, and BishnuDey and the Western Modernist philosophy that has molded their poetic career.
\end{abstract}

Keywords - creative violence, impressionism, surrealism, agnosticism.

"The practice of Rabindranath is poetry became unsuccessful to give solace to the mind of Bengali poets. At least, a few important Bengali poets tried to step aside and avoid Rabindranath and welcomed the positive or negative vision of Mallarme, Paul Verlaine, Rossenr, Yeats or Eliot." (Das, Kabitar Katha, p. 24)

I.

Bengali artists straightforwardly took their method from western poetry- especially their 'form'. Inside the historical backdrop of world verse, we have had seen first the predominance of classic poetry, then romantic poetry lastly modern. Bengali poetry also had three streams like English poetry. Commentator ManjubhasMitra enunciated that "Bengali poetry was directly influenced by the western poetry, and this influence was really reasonable" (Mitra, p. 25). After the WW I, a couple of youthful artists showed up inside the Bengali poetry whose top notch writings changed the substance of Bengali writing in that period. Nineteen Thirties turned out to be for the most part recognized by the five writers - Jibanannada Das, Buddhadev Bose, Bishnu De, SudhindranathDatta and Amiya Chakrabarty. Other than those essayists, HemchandraBagchi and AjitDatta were additionally the first-rate poets of the $30 \mathrm{~s}$.

More youthful Bengali writers endeavored to avoid the bearing of romantic Rabindranath. The Bengali artists had been occupied to finding another bearing of composing. They went up against unquenchable pain, this is the reason they were stimulated by preceding poets' writings, for example, JatindranathSengupta's Skepticism, MohitlalMazumdar's Materialism, PramathaChaudhuri's Objectivity, Najrul's Passion and Satyendranath Dutta's Parody. Jibanananda's 'Kabitar Katha' and Buddhadev Bose's few expositions communicated this reality. MohitlalMazumdar and JotindranathSengupta had been the transitory writers of modern Bengali poetry. We have seen Swinburne, John Donne and Rossetti's effect on Mohitlal's verse. Modern artists wanted to show more advanced poetic vision in their compositions than their ancestors.

European writers like S. High-roller, Wilt Anden, Isherwood, Day Louis - Bengali writers Buddhadev Bose, Jibanananda Das, Bishnu De, Sudhindranath Dutta and Amiya Chakraborty really saw the worldwide financial and spiritually emergency through their severe experience of life. BishnuDe's 'BekarBihango', Buddhadev Bose's 'Bideshini' is superb in this context. Moreover, they saw that this dangerous situation was basically a repercussion of an impersonal economic gadget. When they pondered it, their humanity and aesthetic conviction end up being burdened.

The poets of 30s bring new tune, and new ethos after Rabindranath and their new kinds of poems tend to put beside the abiding dream of art to the disarrayed reality of history. They have deliberately shaken off Tagore's romanticism, eternal form of love devoid of desire, and his mystic Lord of life as they fail to take in the inner voice of imagination. Rather being influenced by Sigmund Freud they have discovered only libido activities underneath the divine grace of love as Freudians-psyche analysis 
overpowers the illusive, and enchanting romanticist's idea of love. Freudian dream analysis not only breaks the perpetual ideology of love but also the style and matter of modern Bangla poetry. Like a dream the logical sequence of images of a poem has been replaced by emotional sequence and suggestive expression of subdued desire. Jibonanonda Das, the true representative of modernism, perceives that traditional values and romantic sense of wonder have already been shattered in the post-war world. So, in his poems image of autumn expresses decay, emptiness, and infertility like Eliot's 'Waste Land' as Das fails to present mellowness and richness of Autumn like Keats. BuddaDev ascertains that Tagore, representing love as abstract and formless ideology just illogically escapes the reality of physical desire and so BuddaDev turns to D.H Lawrence. Shudhindranath's yearning for classical strictness, sculpture-like firmness take him to the French symbolists. Bishnudey is the only one who not only follows T.S Eliot as Mentor but implements his theory. In addition,Amio Chakrabarti in spite of being a mystic and having a philosophic mind fails to achieve Tagore's tranquility. Being influenced by G.M Hopkins, he attains a particular kind of wisdomcontrolled mysticism though; he cannot subdue the whirlwind and affliction that a modern man inherits.

Bengali writing, especially poetry, of the 30 s was unmistakably obligated to western present day verse of T.S. Eliot, Ezra Pound, T.E. Holme, Amy Lowell, Hilda Doolittle et cetera. While we need to catch the fundamental points of view of Bengali present day Poetry and its connection with the social wonders which delivers a pristine area of writing - we appear to be social emergency. This social crisis came to fruition inside the circle of Bengali writing in the time of the 1930s.

Poet of 30s follows Baudelaire, Mallarme, Valery and other French Symbolists and disillusioned idealists, who sought in poetry an escape from the ugliness, hypocrisy, and alienation and disorder of modern mind, and resolved the contradictory conditions of dream and reality into an absolute fact, a super-reality. Later they were influenced by the Imagist movement of Ezra Pound and Eliot's idea of poet's extinction of personality and sense of tradition. Andre Breton's surrealistic movement also has an enormous impact on some of the poets of Kollol-era

II.

Among the modern poets of 30s, AmioChakraborti appears the most complex and split personality. Apparently, he seems mystic, however, he could not achieve tranquil spiritual faculty like Tagore. It is as if a still and motionless ocean that contains a whirlwind and restlessness caused by immersed rock beneath its surface. Any discussion regarding western influence on the poets of thirtees is bound to be incomplete without an analysis of Hopkins's influence on AmioChakraborti. Just like a sea, his contemplative congruity is apparently misleading as it is based on the affliction, complexities, and restlessness of modern mind. He attempts to blend mysticism with materialistic and scientific awareness. In this matter, he has the definite influence of Hopkins. Both achieved wisdom controlled mystic recognition, and their poetic selves were divided between the materialistic world and the world of contemplation. However, both of them believe in the ultimate goodness of the universe and organic oneness of all things and beings. Being influenced by Hopkins mystic theory of inscape and instress, he applies the Uponisodic vision of the oneness of the universe.

Like Hopkins, he produces creative violence by the metrical and grammatical disorder. Their effort is like impressionist's technique, observing a thing from various lights and muddled stain of color paint they catch the sentient and vigorous pulsation of nature. He brings naturalness sometimes by bewildering and disordering grammatical structure and word order. Being influenced by Hopkins, he has introduced sprung rhythm in Bengali poetry and used alliteration and assonance to give a new flavor:

bow or brooch or braid or brace,

Lace latch or catch or key to keep (Hopkins, "The Leaden Eco and the Golden Echo")

AmioChakraborti writes in the same manner:

\section{হটাত রূকে দেয় রূপক; ভুলোয়; দুলোয় (বাস্তবিক, এক্মুঠে)}

27)

(Cakrabarti, p.

(Suddenly metaphor piles on metaphor, swinging and alluring**)

Example of sprung rhythm in Hopkins and AmioChakrabarti:

I caught this morning morning's minion, kingdom

Of dayligt's dauphin, dapple-dawn-drawn

Falcon, in his riding 
Of the rolling level underneath him steady air,

And striding (Hopkins, “The Wind Hover”)

Amio-Cakrabarti says in the same rhythm:

\section{চোঙ। কালো ছলছলে তল; উপরে চাকতি শূণ্যরংগা}

\section{ইটের ফাটল লাল যবাফুল সাঁওতাল পিতলের}

\section{ঘটী বাটি রাঙ্গা(কুয়োতলা)}

(Cakrabarti, p. 27)

(Hollow pipe. Black and rippling lower part. Colorless, small wheel on the upper part/ Crack of brick,red china rose ,Saotal,colored pots made of brass ${ }^{* *}$ )

Both poets break the grammatical rules in coining new words and phrases. Hopkins makes new words like 'blue-beating,' 'unchilding', heart-fleshed and so on. Like him, AmioChakraborti makes new words, "rodduri", "jibonta", "moronta" "asonnota" and so on.

Amio-Chakrabarti, to some extent, was influenced by Wallace Stevens. Both poets in describing nature avoid perceptive and sensuous beauty; instead they remain suggestiveness and onushongo: for example, he imagines sea as a factory:

\section{নীল কল। লক্ষ লক্ষ চাকা। মর্চে পড়া। শব্দের ভীড়ে}

\section{পুরনো ফ্যক্টরি ঘোরে।}

\section{तিযুত মজুরি খাটে পৃথিবীকে}

\section{বালি বানায়, গ্রাস করে মাটি, ছেড়ে দেয়, দ্বীপ রাখে। (সমুদ্র, খসড়া)}

(Cakrabarti, p. 17)

(Blue factory. Millions of wheels. Full of rust.

A crowd of words.

The old factory is moving.

The earth is working for the wages making sand, grasping earth, Leaving and possessing island ${ }^{* *}$ )

Wallace Stevens says in the same manner:

The light is like a spider.

It crawls over the water.

It crawls over the edges of the snow.

It crawls under your eyelids

And spreads its webs there-

It's two webs. (Stevens, "Tatto") 
Apart from Hopkins and Wallace Stevens, German poet Rilke cast a significant influence on AmioChakrabarti who accepts his poetic ideology, "receptivity and transmission of impression." Influenced by this theory, he presents impressionist technique in new height. To display myriadof lights and brightness, the impressionist painters juxtapose several contrasting colors. Similarly, AmioCakraborti juxtaposes different ideas, fragmented pictures, incomplete sentences, unuttered feelings, vague reflection: for example:

\section{ফেলো ছায়া}

\section{ফেলো রঙ কবিতার কাঁচে}

\section{রঙ্গিন আগুনি কাঁচে।}

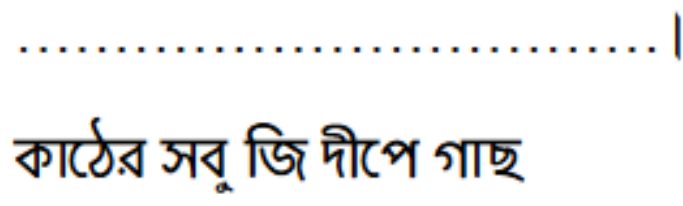

\section{জলের আলোয় নীলে মাছ,}

\section{শাঁখে সাদা ছায়া নাচে}

\section{হ্লুদ বালির নাচে (শঙ্কা ভরন)}

(Drop shade, drop color on the glass of poetry-

(Cakrabarti, p. 17)

Colored and flaming glass.

Tree in the green, wooden island

Fish in blue light of water,

Shadows are dancing in white branch

Dancing on yellow sand ${ }^{* *}$ )

III.

Despondency, dejection, indifference, frustration, agnosticism, fatigue of modern poetry turn into a firm conviction. In the domain of Bangla literature, he is the first existentialist poet. Eliot influences Bishnu day in different dimensions. Firstly, he was influenced by Eliot's idea of his tradition and historical sense. The Western influence on 'MichaleMadhusudanDutt, Tagore, or PromothChowdry was confined to only Homer, Virgil, Dante, or Words worth, and other romantic poets. However, Bishnudey's sense of tradition is far more comprehensive. He spreads his literary horizon from English to France, China, Russia, and America. He enriches his poetic faculty taking experience not only from literature, but from painting, music, dance, plays , Upanishad, and Greek Mythology, Tagore and even from Fairy TALE. He also takes reference from Rabindranath and Kali Das. He employs the symbol of Arjun as well as Hamlet, Artemis as well as Urboshe, revolutionary zeal of Lorka and Aluare; he follows renaissance as well as Dante and Valery; he even takes Chaucer's Cresida and Shakespeare's Ofelia as an objective correlative. The poetic personality of Bishnudeycan be illustrated with T.S Eliot's comment "variety and complexity, playing upon a refined sensibility". However, instead of showing scholarly attitude, he demonstrates an appropriate blending of tradition and individual talent. 
Secondly, BishnuDey was influenced by Eliot's philosophy: the progress of an artist is a continual self-sacrifice and continual extinction of personality. He attempts to free Bangla poetry from subjectivism of Romanticists . Because to be a part of the tradition, he must come out of self-delusive romanticism and attain depersonalization.

To implement Eliot's theory of depersonalization, BishnuDey rejects subjectivity of romantic imagination. He discards the austere devotion in love of Tagore's women, Daymanti, Shakuntala, Mahasheta, or Parboti. To cast off the romantic ideology, he took two Characters from English Literature: Ophelia and Cressida, both of them are charged with the breach of the eternal devotion of love. Dey uses these two characters as objective correlative by which he shatters romantic subjectivism. Ofelia and Cressida become the symbol of fragmentation of love in the modern period.

\section{ক্রেসিডা! তোমার থমকান চোখে চমকায় বরাভয়।}

(Cresida! Overwhelming fear is in your astounded eyes. ${ }^{* *}$ )

\section{হেলেনের প্রেমে আকাশ বাতাসে ঝঞ্ঞার করতাল}

\section{দ্যুলোক ভূলোক দিশাহারা দেবদেবী। (ক্রেসিডা)}

(Dey, p.10)

(Helen's love permeates the sky and air with clapping of thunder

Puzzled gods are in heaven and earth. ${ }^{* *}$ )

Bishnudey in this way discerns the fragmented form of love in the sense of tradition and depersonalization.

The fatigue, meaninglessness, and spiritual barrenness of modern era that Eliot witnessed and reflected in his Waste Land also influenced BishnuDey as he witnessed this modern anxiety and alienation in subjugation and colonization of the sub-continent, the futile endeavor of youth, breathless and complicated lifestyle and dehumanized natural phenomena in city life of Kolkata. In the Waste Land Eliot exquisitely expresses this spiritual infertility through the symbol of wasteland and BishnuDeyexpresses through "chorabali":

\section{চাঁদের আলোয় চাঁচর বালির চড়া}

\section{এখাণে কখনও বাসর হয় না গড়া}

\section{(Dey, p.7)}

(In the moonlight appears only curled sand's pile

Wherebride chambers cannot be formed ${ }^{* *}$ )

In the Waste Land T. S Eliot says:

Here is no water but only rock

Rock and no water and the sandy road. (The Waste Land)

In depicting the emptiness of modern urban life, the sense of fatigue, listlessness, alienation, witty but meaningless verbal exchange of man and women BishnuDey made a conscious imitation of Eliot.Sick, pale and decayed picture of civilization was represented by both poets in the same approach:

Let us go then, you and I

When the evening is spread out against the sky

Like a patient etherized upon a table. ("The Love Song of J Alfred Pufrok")

Bishnudey says: 


\section{সন্ধ্যার ধোয়ার মুঠী উঠি আসে সুচুতুর}

\section{রুদ্ধ করে নিশ্বাস প্রশ্বাস}

\section{বাষ্পগন্ধ স্পঞ্জ হাতে}

(Handful of evening smoke seems sly

(Dey, p.7)

Breath becomes suffocated

The smell of vapor sponge in the hand ${ }^{* *}$ )

This barren civilization produces some hollow men like Prufrock whose shadow we find in BishnuDey's poem 'Janmastomi.'

\section{এই যে অলকা তোমার পাশে}

\section{কে পারে থাকতে ফূরতিহীন}

\section{সুরেশতো রোজ বিকেলে আসে}

\section{যা বোলেছ তুমি, তোমার কিন্তু শাড়ীর রঙ}

\section{আমার চোখ তো নেশাই ঘনায়}

(Hey Alaka, remaining beside you

(Dey, p.7)

Who can be dull and cheerless?

Suresh comes every afternoon

However, the color of your sharee is awesome

My eyes are intoxicating ${ }^{* *}$ )

Eliot says

In the room, the women come and go

Talking Michelangelo (“The Love Song of J Alfred Pufrok”))

BishnuDey, in this way discerns the fragmented form of love in the sense of tradition and depersonalization.

Influenced by Paul Eluard and Louis Aragon, he later has accepted Marxism as his poetic creed. Second World War, communal riots, famine and prospects of the division of India troubled Dey. At this stage, we observe his transition from modern mode to the progressive humanism of Marxist socialism. In his poem 'Ghorsoyar' he visions the impending revolution. In this verse the horseman functions as the objective correlative of social revolution:

\section{হাল্ধা হাওয়ায় হৃদয় আমার ধরো}

\section{হে দূর দেশের বিশ্ব বিজয়ী দিপ্ত ঘোড়সওয়ার}

(My heart is overflowing with the light air

(Dey, p.7) 
Hey, all-conquering, a burning horseman of a remote realm ${ }^{* *}$ )

IV.

Among the modern poets, Jibinanonda Das could exquisitely present afflicted and modern agnostic mind. We get in his poem reflection of Yeatsian idea-man can embody truth, but he cannot know it. BuddaDevbelieves in love, BishnuDey believes in Marxism and equality of society; AmioChakrabarti in spite of having modern dilemma has belief in dibbodrishti.(English). Even atheism and altogether negative attitude of Sudindranath give him a kind of belief in his poetry. However, Jibananda's is so afflicted with modern dilemma and morbidity that his poem is more poignant than others. Like BuddaDey Bose, he has perceived that the emancipation of Bangla poetry lies in avoiding Tagore.

His first work 'JharaPalak' was published in 1927. Then he published DhusharPandulipi (1936), BanalataSen (1942), Mahaprithivi (1944), SattiTararTimir (1948). Aafter the poet's death two more works were published,Ruposhi Bangla (1957) and BelaAbelaKalbela (1961). Jibanananda Das was decidedly conscious about his era. He had a profounduniformity in his thoughts. However we can divide his poetic distinction into three phases - preparation, matured and analytical phase. The first phas consists 'JharaPalak', second 'DhusharPandulipi', 'BanalataSen' and 'Mahaprithivi', and the rest make up the third phase of his poetic self. Post WW I poets were really influenced by Satyendranath, Nazrul, Jatindranath and MohitlalMazumdar. In his first stageJibanananda was also influenced by them. This young poet wanted to avoid Rabindranath in his poems but he could not properly shun Rabindranath. His first book of poems JharaPalak was really influenced by Kabiguru Rabindranath Tagore's 'Balaka'. SatyendranathDatta, Nazrul Islam, JatindranathSengupta's historical consciousness and forceful youth and at the same time Jatindranath's pessimism deeply gripped the mind of Jibanananda Das. Not only that Mohitlal's physical materialistic thoughts also influenced poet JibananandaDas's mind. The poet's 'JharaPalak' inherited from previous works of other poets. Though this book exhibited his primary poetic characteristics. The 'Nabik' and 'Kabi' - these two poems indicate his nature consciousness, epoch consciousness and history consciousness.

He has reflected the end of romanticism and its sense of beauty and wonder in his poems. Apparently, he was influenced by T.S Eliot who in his Waste Land demonstrates the infertile Modern era. Jibonananda Das shows it in his poem 'AbosorerGaan.'()

\section{বাঁশ পাতা-মরা ঘাস- আকাশের তারা!}

\section{বরফের মত চাঁদ ঢালিছে ফোয়ারা!}

\section{ধানক্ষেত- মাঠ}

\section{জমি ছে ধোঁয়াটে}

\section{ধারালো ক্য়াশা!}

(Bamboo leaves, dead grass stars of the sky

the ice-like moon is pouring the spring of water

paddy field- meadow

smoke is gathering

sharp fog ${ }^{* *}$ )

The atmosphere surrounding him is full of decayed, emaciated, tattered and worn out imagery. He introduces a rotten world where the earth is lighted not with the bright ray of sunlight rather the dim beam of ice like the moon. In employing sensuousness, he was influenced by the romantic poet Jhon Keats and French poet Baudelaire as he has given a new dimension to it adding synesthetic and concrete imagery.

Among the Bangla poet of 3os, Das is the direct follower of Yeatsian poetic mode. Like Yeats, Das has a strong love for the world of myths and Legends. Both poets several times employs ephemeral beauty of autumn and melancholic sensuousness: 


\section{দেখেছি সবুজ পাতা অঘ্রানের অন্ধকারে হয়েছে হলুদ}

\section{হিজলের জানালায় আলো আর বুলবুলি করিয়াছে খেলা,}

ইদুর শীতের রাতে রেশমের মতো বোমে মাখিয়াছে খুদ,

\section{চালের ধৃসর গন্ধে তরস্সেরা রূপ হয়ে ঝরেছে দু - বেলা। (মৃত্যুর আগে)}

(Das,ShrestaKabitaSamoagra, p. 111)

[I have seen the green leaves turning yellow in the Autumn darkness

the light of Hijal appears, and a Nightingale is playing

In the winter night, the mice blend the grain in its soft tuft like silk

The waves being beauty are flowing twice in the grey smell of rice $\left.{ }^{* *}\right]$

Yeats says:

Autumn is over the long leaves that love us,

And over the mice in the barely sheaves;

Yellow the leaves of the rowan above us

And yellow the wet wild strawberry leaves. ("The Falling of the Leaves")

Das is the pioneering figure in introducing surrealism in Bangla literature. In the early 20th century, surrealism revolted against modern impressionist technique. Jibonanonda das was both impressionist and surrealist. As an impressionist he appears very subjective in observing the same object into various lights. So the light of dawn seems to him sometimes blue, sometimes green:

\section{কচি লেবু পাতার মত নরম সবুজ আলোয়}

\section{পৃথিবী ভরে গিয়াছে এই ভোরের বেলা; (ঘাস)}

(Das, Shresta Kabita Samoagra, p. 142)

( With the soft light of morning like green lemon leaves

The earth is filled with ${ }^{* *}$ )

Jibonanonda Das was a pioneering figure in introducing surrealistic poems in Bengali literature. He was influenced by other literary movements, like expressionism, cubism, etc. He was also much influenced by Garman literary movement expressionism; especially, the expressionist writer Gotfreedven.has great impact on him. The expressionists tend to present distortion, chaos, sickness, grotesque or caricature. JibonanondasDas's poem 'At Bochor Age Ekdin' is an exquisite expression of expressionism:

থরথুরে অন্ধ পেঁচা এসে

বলেনি কি; ‘বুড়ি চাঁদ গেছে বুঝি বেনোজলে ভেসে

চমৎকার !

ধরা যাক দু-একটা ইদুর এবার!’ (আট বছর আগে একদিন)

(Das,ShrestaKabitaSamoagra, p. 164)

[An old , decrepit, and blind owl

Don't say the olden moon has fallen away 
Wonderful

Let us catch several mice**]

The following absorbed, obscure, and indistinct expression make it an expressionist poem:

\section{আর এক বিপন্ন বিষ্নয়}

\section{আমাদের অন্তর্গত রক্তের ভিতরে}

\section{খেলা করে;}

\section{আমাদের ক্লান্ত করে,}

\section{ক্লান্ত - ক্লান্ত করে; (আট বছর আগে একদিন)}

(Das,ShrestaKabitaSamoagra, p. 164)

[There is some other perilous wonder

That frolics

In our very blood.

It exhausts us-

Exhausts, exhausts us.

That exhaustion is not present $\left.{ }^{* *}\right]$

Jibonanonda Das has searched for truth sometimes in the sense of history, often in social consciousness, or in sensuousness, even in the depth of subconscious mind. Influenced by the French surrealist Andrew Breton's theory of 'a method of spontaneous method of writing and dream analysis, Das as a surrealist creates 'pure psychic automation' in many of his poems:

\section{দুই স্তর অন্ধকারের ভিতর ধুসর মেঘের মত প্রবেশ করলাম}

\section{সেই মুখের ভিতর প্রবেশ করলাম। (শ্রাবন রাত)}

(Das,ShrestaKabitaSamoagra, p. 161)

[I entered into the two layers of darkness

And entered into the mouth**]

Entering into somebody's mouth is possible only in dream reality. Here the poet along with his experience and remembrance goes deep into the sub-conscious mind.

V.

In the history of Bangla literature immediately after the Kollol era, the era of the 30s appears synonymous with the anti-Tagore stance as the poets of 30s deliberately shakes off Tagore's romantic notion, and ideology. Post-war itself is the backdrop of their conscious revolt against the established norm, that is romantic subjectivism, ultimate goodness of the universe, divine grace and eternal love. These poets were also troubled by the communal riots impending partisan of the sub-continent and dehumanized impact of colonization and subjugation. The poets of 30s being the professors of English Literature and journalist in the English press, transmit the Western philosophy and instill it into our Bangeli poetry which is then dynamically overmastered by the wave 
of Western modernism. As they are convinced by the fact that the deliverance of Bengali Literature lies in casting off Tagore's romantic notion, theyhave carried out and adopted different modernist literary techniques and ideology in Bengali literature.

** Alltranslations from Bangla to English are done by the author.

\section{REFERENCES}

[1] Cakrabarti, Amio. Bangla KabitaSanvar.Sahittasamvar: np, 2013. Web.

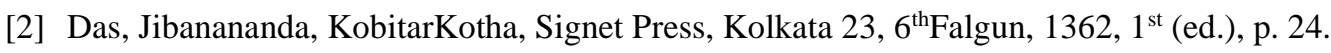

[3] Das, Jibanananda. ShrestaKabitaSamoagra. Dhaka: Rabeya Book House, 2014. Print.

[4] Dey, Bishnu. KabiderKatha.Milansagar:np, 2006. Web.

[5] Eliot, T S. T S Eliot Poems. Poemhunter.com. Web. 13 February 2017.

[6] ManjubhasMitra, Adhunik Bangla KobitayeEuropioProbhab, Dey'sPublishing, Kolkata - 73, January 2002, 1st (ed.), pp. 912.

[7] Stevens, Wallace. Wallance Stevens Poems. Poemhunter.com. Web. 13 February 2017.

[8] Hopkins, G M. Gerard Manley Hopkins Poems. Poemhunter.com. Web. 13 February 2017.

[9] Yeats, W B. W B Yeats' Poems. Poemhunter.com. Web. 13 February 2017. 